\title{
Is the Revascularization Strategy and Outcome Different in Patients with Acute Coronary Syndrome in COVID -19 pandemic Era:A tertiary centre experience
}

ibrahim aktürk ${ }^{1}$, Dilay Karabulut ${ }^{2}$, Ersan Oflar ${ }^{2}$, sait ertığrul ${ }^{1}$, veli polat ${ }^{1}$, alparslan şahin $^{1}$, feridun koşar ${ }^{1}$, ibrahim halil bayrak ${ }^{1}$, atilla koyuncu ${ }^{1}$, ilayda bostanc ${ }^{1}$, fahrettin katkat $^{3}$, aysun karahan ${ }^{1}$, Kudret Keskin ${ }^{4}$, and nihan çăglar ${ }^{1}$

${ }^{1}$ Istanbul Bakirkoy Dr Sadi Konuk Egitim ve Arastirma Hastanesi

${ }^{2}$ Istanbul Bakirkoy Dr Sadi Konuk Training and Research Hospital

${ }^{3}$ Istanbul Bagcilar Training and Research Hospital

${ }^{4}$ Sisli Hamidiye Etfal Training and Research Hospital

December 8, 2020

\begin{abstract}
Objectives: Coronavirus disease of 2019 (COVID 19) became a major public health issue, causing millions of deaths world wide. The burden of COVID 19 pandemics on access to medical care and the treatment of patients with chronic diseases and acute coronary syndromes (ACS) is not fully determined yet. . Methods: A total of 239 patients with ACS were enrolled into the study. Patients were divided into two groups. First group was prepandemic group consisted of patients admitted at January and February 2020, before the pandemic. Second group was consisted of ACS patients admitted through April and May 2020 during pandemic. Both groups were compared according to demographic properties, blood chemistry findings, angiographic features, revascularisation strategies and clinical outcomes. Results: During pandemic period we observed an increase in total number of patient with ST elevation miyocardial infarction (STEMI) patients compared to prepandemic period ( 59(45\%) vs $32(29.6 \%)$ respectively). Initial high sensitive troponin and CK-MB levels were statistically higher in the pandemic group patients $(1953 \mathrm{pg} / \mathrm{ml}$ vs $259 \mathrm{pg} / \mathrm{ml}$ for troponın I and $14 \mathrm{ng} / \mathrm{ml}$ vs $6 \mathrm{ng} / \mathrm{ml}$ for CK-MB $\mathrm{p}<0.0001, \mathrm{p}=0.02$ respectively). TYPE 4a myocardial infarction due to stent thrombosis was more frequent in pandemic group relative top re-pandemic group (10 vs $0 \mathrm{p}=0.003)$. Post procedural TIMI flow grade was lower in pandemic group and distal embolization and TIMI thrombus score were significantly higher in the pandemic group compared top re-pandemic group (, $\mathrm{p}=0.001, \mathrm{p}=0.02$, $\mathrm{p}=0.002$ respectively). However; there was no statistically significant difference in hospital mortality and short -term all cause mortality, among groups ( $\mathrm{p}>0.05)$. Conclusion: We observed that although clinical, laboratory, and angiographic features were worse in ACS patients admitted during the pandemic compared to pre-pandemic period, the mortality rate of ACS was similar. It is important to keep coronary care units open and fully-functioning during the pandemic.
\end{abstract}

\section{Hosted file}

main text.pdf available at https://authorea.com/users/381893/articles/497835-is-therevascularization-strategy-and-outcome-different-in-patients-with-acute-coronarysyndrome-in-covid-19-pandemic-era-a-tertiary-centre-experience

\section{Hosted file}

table 1.pdf available at https://authorea.com/users/381893/articles/497835-is-therevascularization-strategy-and-outcome-different-in-patients-with-acute-coronarysyndrome-in-covid-19-pandemic-era-a-tertiary-centre-experience 


\section{Hosted file}

table 2.pdf available at https://authorea.com/users/381893/articles/497835-is-therevascularization-strategy-and-outcome-different-in-patients-with-acute-coronarysyndrome-in-covid-19-pandemic-era-a-tertiary-centre-experience

\section{Hosted file}

table 3.pdf available at https://authorea.com/users/381893/articles/497835-is-therevascularization-strategy-and-outcome-different-in-patients-with-acute-coronarysyndrome-in-covid-19-pandemic-era-a-tertiary-centre-experience

\section{Hosted file}

table 4.pdf available at https://authorea.com/users/381893/articles/497835-is-therevascularization-strategy-and-outcome-different-in-patients-with-acute-coronarysyndrome-in-covid-19-pandemic-era-a-tertiary-centre-experience

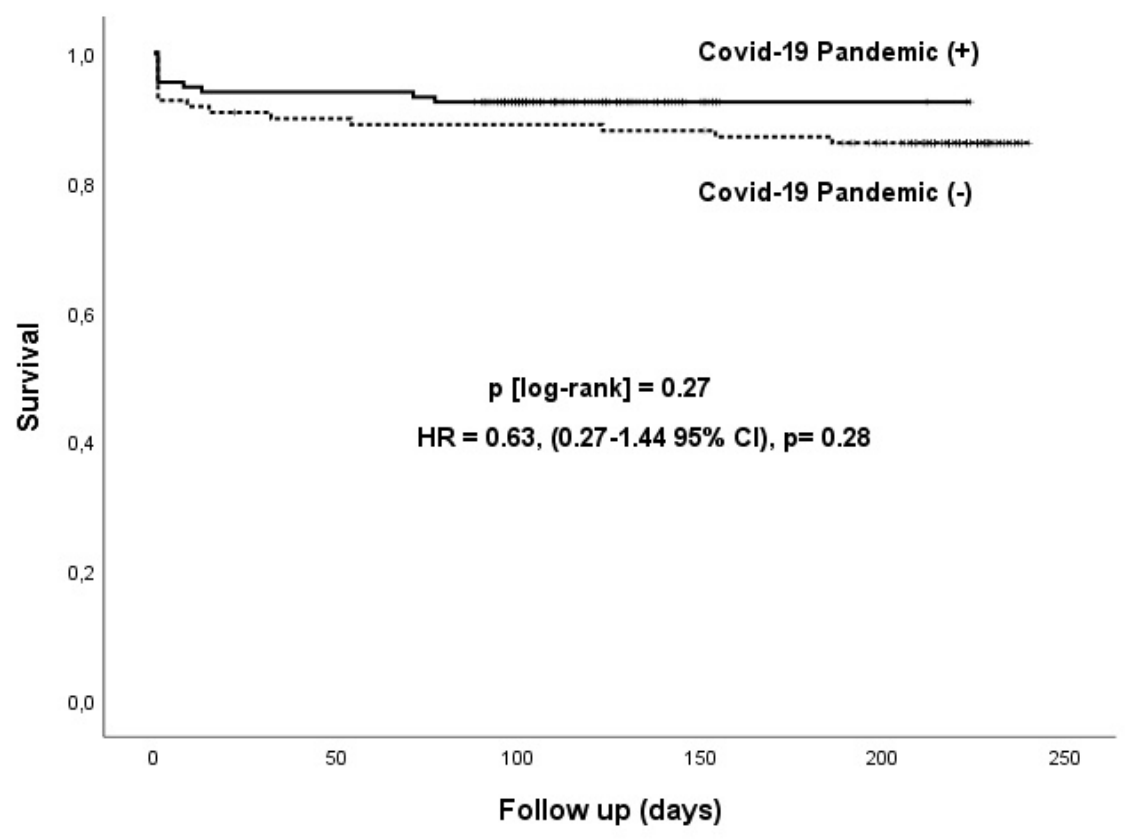

